Article

\title{
Hermeneutic and Teleology in Ethics across Denominations-Thomas Aquinas and Karl Barth
}

\author{
Jacqueline Stewart \\ Department of Theology and Religion, University of Exeter, Exeter EX4, UK; jacqueline.stewart@exeter.ac.uk ${ }^{1}$
}

Received: 17 August 2017; Accepted: 17 September 2017; Published: 27 September 2017

\begin{abstract}
This study arises from the context of current debates in the Catholic Church on the place of rule and law in moral reasoning. I suggest that ethics may be best served by approaches that place the human subject in a teleogical context and that recognise the need for interpretation of circumstances surrounding actions to be evaluated. This is in contrast to normative rule approaches. The insights retrieved from the account of moral reasoning in Thomas Aquinas by Joseph Selling are compared with an account of the ethical implications of Karl Barth's theology of hope as expressed in Volume Four of the Church Dogmatics. It is concluded that, in an ecumenical convergence, neither propose a normative rule approach. Rather both use a teleological context and require a hermeneutic of evaluation.
\end{abstract}

Keywords: moral theology; ethics; hermeneutics; discernment; moral development; intention; Thomas Aquinas; Karl Barth

\section{Introduction}

A contemporary 'reframing' may be indicated for moral theology and ethics across the whole range of denominations and even religions. There are historical factors in play including changes in social, economic and political spheres in Western Europe. The first half of the twentieth century, marked by two world wars, was nevertheless a period of general social conformity, with widely accepted social values on matters such as sexual behaviour, citizenship, social and political institutions. After the end of the Second World War, the so called 'post war consensus' was increasingly disturbed and in the succeeding fifty years, broken up entirely. Changes in the role of women and the family, enabled by the advent of safe contraception, challenges to economic theory and distrust of the role of authority after the excesses of the war, were associated with an increasing individualism, and desire for personal freedom. More extreme political positions emerged, including the rise of right wing politics which looked back to the emotional security of the pre-war certainties. The shrinking of the effect and influence of social institutions was accompanied by increasing secularisation. The churches lost members and influence, and their right to a voice in public discourse became more precarious. Calum Brown's study on the decline of church influence, particularly the last chapter, (Brown 2001) and Tony Judt's contribution on economic changes (Judt 2010) are among many which provide insights into some of these changes.

These trends were paralleled by change within the churches. In the Catholic Church, the Second Vatican Council allowed the dissatisfaction with the imposed conformity of the preceding era to be expressed. It matched the ferment and flowering of ideas that was being expressed in secular society. In the following decades, it was succeeded by increasing concern about secularisation and the loss of church influence. Matching the rise of ultra conservative politics outside, currents in the Church

1 The author is also an Honorary Senior Lecturer in Theology at the University of Leeds, Leeds LS2 9JT, UK. 
favoured a return to conformist values and practice. Church members valued certainty and wanted moral guidance in a pluralist and chaotic world.

This is part of the background to the contemporary debates in moral theology and ethics. In the Catholic Church, there is a significant debate about the status of moral laws and rules, with a spectrum of views. At one end, there are those influenced by the reforms of Vatican II, who regard moral laws and rules as necessary but not sufficient, potentially ambiguous and therefore neither normative nor certain in all situations. At the other end, there are those who are concerned by the loss of the Church's role in society since Vatican II, and who regard moral law as primary, unambiguous, normative for all action and certain as a guide to right action. This debate obtains in Protestant theologies as well as in Roman Catholic ones. It has practical consequences in that, on one hand, the existence of normative rules supports cohesion within groups, and strengthens their identity in the face of unwanted outside influence. On the other hand, an interpretative approach to ethical decision making allows for pastoral sensitivity, and is flexible when encountering new problems.

In the Roman Catholic Church, an actual controversy has developed between those at each end of this spectrum. For instance, the encylical Veritatis Splendor promoted a narrow reading of natural law and stressed a revisionist evaluation of action against rule or law. More recently, those following the more expansive ideas expressed in Vatican II have been given more of a hearing. In preparation for the consultation of bishops by Pope Francis at the 2014 Synod on the Family, Bishop Bonny of Antwerp noted that after the publication of the encyclical Humanae Vitae, official Church teaching was often identified with a version of the normative rule approach. At the same time, representatives of other approaches were, he said, "consigned to the corner as suspicious and to be avoided." They included "highly meritorious theologians ... Josef Fuchs SJ, Bernard Häring CSsR and L. Janssens (KU Leuven)". He observed that "different moral-theological models have always functioned within the church", and he cites the encyclical Evangelii Gaudium in support of the importance of diverse traditions and argumentation in the pursuit of truth. (Bonny 2014, pp. 9-10). These ideas of moral hermeneutic have been rehabilitated in Amoris Laetitia, notably in Chapter 8, where Pope Francis comments on the need for discernment of situations, and this is discussed elsewhere in this journal.

\section{2. 'End' to 'Intention' to 'Act'; Teleological Priority and Hermeneutic Necessity in Thomas}

Against the foregoing background, the contributions of Joe Selling to the Catholic tradition can be seen to be very important He studied with Louis Janssens (Janssens 1988) and has expanded and developed the insights that Janssens brought to moral theology (Selling 2016). These emerged from the re-reading of Thomas that took place before Vatican II, in which the foundational theological intentions of Thomas were re explored. In a major insight, Janssens expounded the distinction Thomas makes between intention, and choice, and the prior moral significance he imputes to intention. Janssens develops this to the conclusion that Thomas does not offer a rule based normativity. Rather, he proposes a process of moral reasoning requiring an interpretation of tradition in which humanity is oriented to the pursuit of the good, and which sees the moral importance of intention, and takes into account the finite and partial nature of human reality. (From this account of moral reasoning in Thomas, the description of moral action as involving the 'human person adequately considered' evolved and found its way into the documents of Vatican II). This also restores the universality of Thomas' position, since orientation to ultimate good and intent to do good in pursuit of that is not restricted to Christians. It seems to me that the key points in Selling's reading of Thomas are firstly, his attention to the structure of the Summa Theologiae as Thomas intended it. Selling points out that Thomas adapted the conventional pattern of medieval theological treatises in his grouping of material. In Part I, Thomas deals first with the actions of God, and then with humanity as created. The implications of this are made clear; the telos of humanity is that it should ultimately flourish with God at the End. By virtue of being created by God, humanity is called or oriented to the good. Thomas is interested in voluntary acts, that is, those resulting from the operation of the will, because only those are subject to moral evaluation. His understanding of will is that it is the "intellectual appetite, whereby the person 
is attracted towards that which is apprehended as true and good" (Selling 2016, p. 59). His reading of the human being parallels Aristotle; nobody does things that they think are bad for themselves at a foundational level. That is, what is desirable presents as what is good. The ideas that people have about what is good may be perverted, but the foundational orientation of the human is to what is perceived as good. (Selling 2016, pp. 59-60). Thomas describes human beings as characterised by capacity, capability or agency. Only in Part II Section 1 of the Summa does Thomas come to the specifics of the capacity for moral reasoning and behaviour, and in Part II.2 to the dispositions helpful to developing it. Selling demonstrates convincingly that Thomas sees moral or ethical behaviour as resulting from a process, (which Selling terms 'the moral event') originating in the divinely created human capacity for orientation to the good. Thomas begins with the evaluation of the end or goal of action. Thomas says "the end is last in execution, but first in intention of reason, according to which moral actions receive their species" (Selling 2016, p. 62). Selling contends that Thomas then works through the components of a 'moral event' from the overall goal through intention and aspects of context to the concrete behaviour. Selling summarises this in his schema, which is discussed elsewhere in this journal,

"End > intention > circumstances > behaviour > act/object " (Selling 2016, p. 170)

In this account of moral decision making and reasoning, the human telos, the orientation to God as ultimate, drives intention which requires interpretation of circumstances, hermeneutics, to formulate behaviour. Selling argues that while Thomas was concerned with the basic ethical commitment of a person, those who came after him were more interested in specific behaviours. Consequently, generations missed the significance and value of his discussion, and focused on objectified virtues and vices instead. This oversight may have contributed to the predominance of rule based thinking in the moral theology of the eighteenth and nineteenth century manuals. Daniel Westberg offers an approach to Thomas which converges with Selling, (Westberg 2015), in distinction to the many who would maintain a contrary view, e.g., Sevais Pinckaers (Pinckaers 2001).

It seems that Selling's recovery of insights from Thomas, via the approaches that were present in Vatican II, may alter the balance of argument between those advocating normative rules and those advocating an interpretative context in the Roman Catholic tradition. What of Protestant approaches to moral and ethical thinking? Karl Barth is often described as one of the most significant Protestant theologians of the twentieth century (Webster 2000). His approach to moral reasoning may yield some valuable insights in the context of the foregoing discussion.

\section{Barth and Contemporary Protestant Ethics}

There is a vast literature on Barth's ethics. Work in English can be divided rather arbitrarily into three phases. There was an early phase in the 1970s, when some authors began to explore some the radical implications of Barth's theology-for example, the notable Gifford lectures by Stanley Hauerwas (Hauerwas 2001). Then there was a phase in the 1990s when authors such a Nigel Biggar re-examined the ethical dimension of Barth's foundational theology (Biggar 1993). And most recently, in the last decade and a half, there has been a turn to so called 'Protestant Thomism', which often draws on Barth for support. Recent work includes the compilation of essays in Commanding Grace (Migliore 2010), Behaving in Public (Biggar 2011), Aquinas as Authority (Van Geest et al. 2002) and articles such as 'Practical Wisdom and the Integrity of Christian Life' (Werpehowski 2007). The whole issue of Studies in Christian Ethics in 2013 was devoted to this area. The major part of all this work has mostly been associated with attempts to recover an approach to natural law consonant with contemporary protestant sensibilities, as part of an attempt to create an ethical discourse that can meet secular debate in the public arena on common ground. This is likely to prove a hard row to hoe, not least because Barth himself specifically objected to rule based ethics, and objected very definitely indeed to arguments from natural law. His objections stem from his foundational concern to allow God to speak from scripture and tradition, rather than allowing 
human projections onto scripture and tradition to create idolatrous versions of God. Barth did not ignore the questions about how people can act rightly, but he had very different answers from his contemporaries. Webster encapsulates Barth's view when he says "Barth takes a radically different approach: describing the moral field is not a matter of analysing judgements made, but of portraying the encounter of God with humanity with as much density as possible" (Webster 1995, p. 100).

Before Barth's approach to ethics can be set out, it is essential to explore the issue of his use of language. A proper understanding of Barth, like Thomas, requires that parts are read in the light of the whole. Barth uses the language of "command", "summoning", "response" etc. in the context of human response to the "Word". To make sense of this, it is helpful to know that every significant word in Barth is written in the context of the direct relation of God and humanity. As used by Barth, these words can be only be properly understood when redefined in the light of the Christ event. The commands that Jesus gives and himself responds to are the imperatives of love, and this is what Barth intends. For example, obedience in Barth means a loving response to the call of Christ, not a submission to some kind of objectified power. George Hunsinger has an excellent account of this and other issues raised by Barth's creative use of language (Hunsinger 1991, p. 33ff). Consequently, it is possible to respectfully disagree with, for instance, Nigel Biggar's approach to translating "command" in which he fits various humanly constructed meanings (the military, the legal) to Barth's use of the word (Biggar 2010, pp. 28-31). It may be thought that this misses the fundamental ethical implications of the word as Barth uses it. Given Barth's view of human situatedness, it is not surprising that he sees ethical behaviour and moral action as responsive behaviour and action. It follows that when Nimmo discusses Barth's view of the human being as a moral agent, he asserts that "to answer the ethical question of what it means to be a responsible Christian ... we are directed to Jesus Christ ... we are summoned by this Word of God to obedient action in freedom and love" (Nimmo 2010, p. 232). Here again 'responsible' means responsive in and to love; 'summoned' means lovingly called into love, 'obedient' means freely consenting to love. The invitation to relationship given by the sense of 'God with us' is not an "arbitrary act of the divine omnipotence of grace" (Barth 1956-1975, vol. IV/I, p. 12); it is not being overridden by an impersonal goodness. Rather it is the most loving personal outreach, where God himself involved himself as God and man in "a real closing of the breach, gulf and abyss" (Barth 1956-1975, vol. IV/I, p. 12) between God and humans. The problem is the belief of the human "that he can and should find self-fulfillment. He has himself become an eschaton" (Barth 1956-1975, vol. IV/I, p. 10); that is, humans attempt to become their own end and goal, thus perverting their proper destiny. Rather than this refusal of relation, which constitutes sin, Barth is clear that love is foundational to the Christian response to this call to relationship. Thomas would surely agree with this.

The overall sweep of Barth's thought is set out in his monumental work on theology, Church Dogmatics (Barth 1956-1975), which is structured in four developing sections. Volume One, The Doctrine of The Word, is an account of the possibility of knowing God; Volume Two, The Doctrine of God, is an account of some of what may be known of God; Volume Three, The Doctrine of Creation, is an account of God's foundational activity in relation to humanity. Irrupting into this is the tragic fact of human sin and rejection of God. The story of God and humanity is completed by Barth with Volume Four, The Doctrine of Reconciliation, which includes a treatment of the virtues of faith, hope and charity. It should be noted that these works came to fruition through a time span of over twenty years. There are therefore changes in direction and emphasis as Barth's thinking developed. There is no section in the Church Dogmatics headed 'ethics'. His explicit conclusions on ethical and moral reasoning are mostly found in Volume Four and they center on the practical implications of what faith, hope and charity might mean in the context of the human relation with Jesus Christ. One should bear in mind here John Webster's argument that the whole of the Dogmatics has a foundationally ethical character (Webster 1995, 1998).

An example of the working out of Barth's ethics can be found in his treatment of hope. Barth begins his survey of reconciliation with a summary of the core of the Christian message that Jesus Christ is the cosmic reconciler, and is the fundamental and foundational renewer of all reality (Barth 1956-1975, vol. IV/1, p. 3). Consequently, humanity has indeed certain hope in God, 
because nothing could be more certain and reliable than the faithfulness of God in Jesus Christ, and that hope is sustained and empowered by the Spirit. The formation of the Christian community follows the Spirit's empowerment of the human response to the invitation to hope in Christ. Barth notes the key features of such hope-empowered life, active engagement in community, and enervation by a non- simplistic vision of the Holy Spirit. All of these have ethical implications.

\section{An Example: Barth on the Ethical Implications of Hope}

Firstly-For Barth, hope is not about judgement and the last things. Hope is not hope for things but rather in Christ, in a person. Hope is explained in the context of community, the body of Christ in whom Christians hope, and it has ethical implications, as being in a relationship of hope and trust transforms the life of the Christian. It also stands clearly as distinct from human expectation or fate, the mechanical unfolding of determined events. That hope for Barth is both personal and relational hope in Jesus Christ, is further illustrated by John McDowell in his explorations of the Barth-Brunner controversy (McDowell 2006). Interestingly, McDowell cites the support of Rahner (1961-1992); "Christ himself is the hermeneutical principle of all eschatological assertions. Anything that cannot be read and understood as a christological assertion is not a genuine eschatological assertion" (McDowell 2006, p. 35). McDowell is clear that "for Barth, Christian hope is not an expectation of some external object or thing, nor a belief in an automatically unfolding future ordained by some deus ex machina". Similarly, Gerhard Sauter can argue, over against Moltmann (1967), that Barth's theology is not a kind of futurism or 'theology of hope' (Sauter 1999, p. 408).

Hope is what humans are summoned to, it is a calling from God into a relationship with Jesus Christ with all the consequences that entails, and this is surely compatible with Selling's reading of Thomas. The Christian does not project himself into the future by expectation or anticipation, which would be an unreliable proceeding depending on his own finite effort, but is called from the future by Jesus Christ as risen, vindicated Lord. Christian faith, love and hope are focused on the person who calls humanity into relation, Christ. Jesus Christ is both the hope of the Christian and that which makes such hope possible. Barth says of Christian hope that Jesus Christ is

"...the theme and goal and basis of his subjective hope. Nor is it that he merely is his hope...Jesus Christ, who does not merely accompany and precede him in time, who also comes to meet him from its end and goal, makes possible his being as Christian and witness even in the apparently dark time and empty time which is before him, including the hour of death." (Barth 1956-1975, vol. IV/3.2, p. 915).

Here it is clear that hoping in Christ empowers 'being as Christian' and 'witness'; as Webster observes, it involves action, orientation, effectiveness in concrete human life (Webster 1998, pp. 95-96) In fact, hope is a calling to ethical behaviour.

Secondly_At the outset, it can be seen that Barth preserves the priority of God's reconciling activity in respect of human responses to it. Humanity is not saved because people have faith in a particular formula, or are baptised into a particular community, or follow particular practices (Barth 1956-1975, vol. IV/1, p. 4). The possibility of hope is a cosmic reality for all. Barth's account combines both the subjective availability of Jesus Christ as known in the Christian community and his objective reality as cosmic enabler of the hope that community has. Jesus Christ himself is the hope of both Christians and also non-Christians. The reality of hope does not depend on conscious knowledge of or about Christ. Barth observes "Whether known now or unknown, He is the future of all" (Barth 1956-1975, vol. IV/3.1, p. 346). Christian hope is not about securing a kind of salvation limited to the self, ('pie in the sky when you die'), but about the promise to all. Note that in Barth, being is always be-ing, an act of a dynamic subject, not a property of a static object. Hunsinger's discussion of actualism illuminates this (Hunsinger 1991). Similarly, for Barth, reconciliation is not a condition, but an ongoing event (Barth 1956-1975, vol. IV.1, pp. 3-6). For Barth, as for Thomas, humans are created, embedded in a relation of love, called and empowered to respond to God's love. And since responsive hope is in Christ, 
it is inevitably a calling or orientation to the ultimate good. Again, Selling's account of Thomas converges on this.

In conclusion, Barth argues that hope leads to concrete witness-a relation of trust in another person brings about change. It can give courage, it can lead to a desire to make a practical response, and it can strengthen shared values and uncover new ones. The responsibility for 'reading the signs of the times', for consideration and evaluation, lies with the human individual. Barth accepts that human intellectual assessment of concrete circumstances involves a process of interpretation, that is, a hermeneutic. Scripture and tradition provide guidance, but the Spirit-empowered person uses what is given in the relation with Christ to choose the best path. Such change also implies effort and struggle against evil and sin. Here again, the commitment to the good is prior and it informs intentions for actions, as in Selling's explication of Thomas. Barth's conception of Christian hope gives it ethical force; Christians are summoned to hope, and hope is participation in a relation with Jesus Christ. He himself, rather than a humanly constructed rule or law, is the practical standard of evaluation for the life that is conferred by the relationship with him. Christian hope is not focused on the individual, but is hope for the community. It is not about expectations of objectifiable benefits for individuals, nor an anticipation of a predictable future, (which can never be certain even from a philosophical standpoint). Rather, it is a gift from Jesus Christ, who is both now and yet to come, which empowers Christians to live ethically in the present and to face what the future may bring.

\section{Conclusions: Consequences for Ethics and Moral Argument}

For Barth, hope as a trusting relationship is an orientation to the good beyond oneself. Trust in the good implies commitment to it. This has practical consequences for behaviour. This idea of human situatedness seem to me to fit reasonably with the first premise that is described by Selling in his reading of account of the human person by Thomas. Human persons are created, redeemed and fulfilled by God, and open to Him, whether or not they are aware of it. I have shown as an example that Barth's treatment of hope clearly brings it within the purview of the goal oriented approach described by Selling. Barth's reading of human situatedness calls for interpretation or discernment by each individual as they work out their personal responses to the divine invitation of love, which parallels Selling's conclusions from Thomas on the need for evaluation of circumstances in moral reasoning. Barth identifies effort and struggle in humanity's discernment of the call to the good which is God. Similarly, the moral event, as Selling sees it in Thomas, is impacted by both human freedom to get things wrong, and God's grace in supporting human attempts to get it right.

Overall, these accounts of Thomas and Barth seem to me to be converging on a much more dynamic understanding of how human beings can try to act ethically or morally than the normative rule approaches. Selling offers a better interpretation of what Thomas intended in his discussion of natural law than those following the revival of natural law. The latter have been extensively critiqued; see, for example, McInerny's essay on Grisez and Thomism (McInerny 2000), and indeed, the whole volume edited by Nigel Biggar and Rufus Black (Biggar and Black 2000). Normative rule based approaches to ethics do not seem to recognise the impossibility, after the philosophical critiques of modernity in the last hundred years, of ignoring hermeneutic as an essential component of the human reception of reality. Further, the 'ethical moment' is different in kind from the 'logical moment'. Deductive logic, applied to set rules whose premises must predict the conclusion, admits of no deviation and no doubt, and is the operation of a self-sufficient, independent agent. The 'ethical moment' is the pursuit of the good against odds, and is always a 'kairos', a moment of grace in which something beyond the self is given. Such an approach can be nuanced in particular human circumstances, and expanded to meet new ethical questions raised by developments in human activity. It can also be communicated in the public space; for example, secular philosophers such as Levinas (1969) and Ricoeur (1992) provide foundational philosophical accounts of ethics which converge on these theological approaches. David Ford points to this in Self and Salvation (Ford 1999, pp. 130-36). This said, such a view of ethics is likely to be challenging to those seeking guidance in a complex and confusing pluralist culture, and effort should be expended on 
rendering the issues intelligible. Nevertheless, I think a conception which includes a both a hermeneutic and a teleological element is essential to any functional discussion of moral reasoning and ethics, and I claim that such is to be found in both Barth and in Thomas.

Conflicts of Interest: The author declares no conflict of interest.

\section{References}

Barth, Karl. 1956-1975. Church Dogmatics. Edinburgh: T \& T Clark.

Biggar, Nigel. 1993. The Hastening that Waits: Karl Barth's Ethics. Oxford: OUP.

Biggar, Nigel. 2010. Karl Barth's Protestant Ethics Revisited. In Commanding Grace. Edited by Daniel Migliore. Grand Rapids: Eerdmans, pp. 26-49.

Biggar, Nigel. 2011. Behaving in Public. Grand Rapids: Eerdmans.

Biggar, Nigel, and Rufus Black, eds. 2000. The Revival of Natural Law: Philosophical, Theological and Ethical Responses to the Finnis-Grisez School. Aldershot: Ashgate.

Bonny, Johan. 2014. Synod on the Family-Expectations of a Diocesan Bishop. September 1. Available online: http:/ /www.associationofcatholicpriests.ie/2014/09/synod-on-the-family-expectationsof-a-diocesan-bishop/ (accessed on 19 April 2017).

Brown, Calum. 2001. The Death of Christian Britain. London: Routledge.

Ford, David. 1999. Self and Salvation: Being Transformed. Cambridge: CUP.

Hauerwas, Stanley. 2001. With the Grain of the Universe. Grand Rapids: Brazos Press.

Hunsinger, George. 1991. How to Read Karl Barth: The Shape of His Theology. Oxford: OUP.

Janssens, Louis. 1988. Time and Space in Morals. In Personalist Morals. Edited by Joseph A. Selling. Leuven: Peeters, pp. 9-22.

Judt, Tony. 2010. Ill Fares the Land. London: Allen Lane.

Levinas, Emmanuel. 1969. Totality and Infinity. Pittsburgh: Duquesne University Press.

McDowell, John C. 2006. Karl Barth, Emil Brunner and the Subjectivity of the Object of Christian Hope. International Journal of Systematic Theology 8: 26-41. [CrossRef]

McInerny, Ralph. 2000. Grisez and Thomism. In The Revival of Natural Law: Philosophical, Theological and Ethical Responses to the Finnis-Grisez School. Edited by Nigel Biggar and Rufus Black. Aldershot: Ashgate, pp. 53-72.

Migliore, Daniel, ed. 2010. Commanding Grace. Grand Rapids: Eerdmans.

Moltmann, Jurgen. 1967. Theology of Hope. New York: Harper \& Row.

Nimmo, Paul. 2010. Barth and the Christian as Ethical Agent: An ontological study of the shape of Christian ethics. In Commanding Grace. Edited by Daniel Migliore. Grand Rapids: Eerdmans, pp. 216-38.

Pinckaers, Servais. 2001. Morality: The Catholic View. South Bend: St. Augustine's Press.

Rahner, Karl. 1961-1992. The Hermeneutics of Eschatological Assertions. In Theological Investigations. London: Darton, Longman \& Todd, vol. 4, p. 342.

Ricoeur, Paul. 1992. Oneself as Another. Chicago: University of Chicago Press.

Sauter, Gerhard. 1999. Why is Karl Barth's Church Dogmatics not a 'Theology of Hope'? Some Observations on Barth's Understanding of Eschatology. Scottish Journal of Theology 52: 407-29. [CrossRef]

Selling, Joseph. 2016. Reframing Catholic Theological Ethics. Oxford: Oxford University Press.

Van Geest, Paul, Harm Goris, Carlo Leger, and Mishtooni Bose, eds. 2002. Aquinas as Authority'. Leuven: Peeters. Webster, John. 1995. Barth's Ethics of Reconciliation. Cambridge: CUP.

Webster, John. 1998. Barth's Moral Theology. Edinburgh: T\&T Clarke.

Webster, John. 2000. Introducing Barth. In The Cambridge Companion to Karl Barth. Edited by John Webster. Cambridge: Cambridge University Press, pp. 1-16.

Werpehowski, William. 2007. Practical Wisdom and the Integrity of Christian Life. Journal of the Society of Christian Ethics 27: 55-72.

Westberg, Daniel. 2015. Renewing Moral Theology. Downers Grove: Intervarsity Press. 